\title{
Selection of reference genes for quantitative RT-PCR studies in Rhipicephalus (Boophilus) microplus and Rhipicephalus appendiculatus ticks and determination of the expression profile of $\mathrm{Bm} 86$
} Ard M Nijhof*1, Jesper A Balk1 ${ }^{1}$, Milagros Postigo ${ }^{1}$ and Frans Jongejan ${ }^{1,2}$

Address: ${ }^{1}$ Utrecht Centre for Tick-borne Diseases (UCTD), Faculty of Veterinary Medicine, Utrecht University, Yalelaan 1, 3584 CL, Utrecht, the Netherlands and ${ }^{2}$ Department of Tropical Diseases, Faculty of Veterinary Science, University of Pretoria, Private Bag X04, 0110, Onderstepoort, South Africa

Email: Ard M Nijhof* - A.M.Nijhof@uu.nl; Jesper A Balk - J.A.Balk@uu.nl; Milagros Postigo - milagrospostigo@hotmail.com; Frans Jongejan - F.Jongejan@uu.nl

* Corresponding author

Published: 29 December 2009

BMC Molecular Biology 2009, 10:1/2 doi:10.1186/147I-2199-10-1/2
Received: 14 July 2009

Accepted: 29 December 2009

This article is available from: http://www.biomedcentral.com/I47/-2199/10/II2

(c) 2009 Nijhof et al; licensee BioMed Central Ltd.

This is an Open Access article distributed under the terms of the Creative Commons Attribution License (http://creativecommons.org/licenses/by/2.0), which permits unrestricted use, distribution, and reproduction in any medium, provided the original work is properly cited.

\begin{abstract}
Background: For accurate and reliable gene expression analysis, normalization of gene expression data against reference genes is essential. In most studies on ticks where (semi-)quantitative RT-PCR is employed, normalization occurs with a single reference gene, usually $\beta$-actin, without validation of its presumed expression stability. The first goal of this study was to evaluate the expression stability of commonly used reference genes in Rhipicephalus appendiculatus and Rhipicephalus (Boophilus) microplus ticks. To demonstrate the usefulness of these results, an unresolved issue in tick vaccine development was examined. Commercial vaccines against $R$. microplus were developed based on the recombinant antigen Bm86, but despite a high degree of sequence homology, these vaccines are not effective against $R$. appendiculatus. In fact, Bm86-based vaccines give better protection against some tick species with lower Bm86 sequence homology. One possible explanation is the variation in Bm86 expression levels between $R$. microplus and $R$. appendiculatus. The most stable reference genes were therefore used for normalization of the Bm86 expression profile in all life stages of both species to examine whether antigen abundance plays a role in $\mathrm{Bm} 86$ vaccine susceptibility.

Results: The transcription levels of nine potential reference genes: $\beta$-actin (ACTB), $\beta$-tubulin (BTUB), elongation factor I $\alpha$ (ELFIA), glyceraldehyde 3-phosphate dehydrogenase (GAPDH), glutathione Stransferase (GST), H3 histone family 3A (H3F3A), cyclophilin (PPIA), ribosomal protein L4 (RPL4) and TATA box binding protein (TBP) were measured in all life stages of $R$. microplus and $R$. appendiculatus. ELFIA was found to be the most stable expressed gene in both species following analysis by both geNorm and Normfinder software applications, GST showed the least stability. The expression profile of Bm86 in $R$. appendiculatus and $R$. microplus revealed a more continuous $\mathrm{Bm} 86$ antigen abundance in $R$. microplus throughout its one-host life cycle compared to the three-host tick $R$. appendiculatus where large variations were observed between different life stages.

Conclusion: Based on these results, ELFIA can be proposed as an initial reference gene for normalization of quantitative RT-PCR data in whole R. microplus and R. appendiculatus ticks. The observed differences in Bm86 expression profile between the two species alone can not adequately explain the lack of a Bm86 vaccination effect in $R$. appendiculatus.
\end{abstract}




\section{Background}

The ixodid ticks Rhipicephalus appendiculatus and Rhipicephalus (Boophilus) microplus are important pests of livestock. Besides causing direct production losses and leather damage due to their blood-feeding habit, both ticks are able to transmit a wide variety of pathogens. Both tick species overlap in their distribution, but $R$. microplus is more widespread and occurs in subtropical and tropical areas of the world whereas the distribution of $R$. appendiculatus, also known as the brown ear tick, is limited to areas with a humid climate from southern Sudan to the southeastern coast of South Africa. Their life cycle differs quite dramatically too: $R$. microplus is a one-host tick species with all life stages feeding on the same, usually bovine, host whereas $R$. appendiculatus is a three-host tick species with each life stage requiring a new host to feed on. As a consequence of this, $R$. microplus can complete its life cycle in less than 2 months, whereas $R$. appendiculatus takes about 3 months to complete its life cycle under the most favorable conditions [1].

Control of ticks worldwide relies principally on the use of acaricides, but two vaccines targeting $R$. microplus were commercialized in the 1990s: TickGARD Plus ${ }^{\circledR}$ in Australia and Gavac ${ }^{\circledR}$ in Cuba. Both are based on the same recombinant antigen named Bm86, a glycoprotein of unknown function which is located predominantly on the surface of midgut digest cells [2]. Although Bm86-based vaccines showed cross-protection against various other tick species, e.g. Rhipicephalus (Boophilus) annulatus [3], Rhipicephalus (Boophilus) decoloratus, Hyalomma anatolicum and Hyalomma dromedarii [4], they were not effective against Amblyomma variegatum and R. appendiculatus [4,5].

Due to the veterinary and economical importance of $R$. microplus and R. appendiculatus in subtropical and tropical areas of the world, expressed sequence tag (EST) datasets for these tick species have been established [6-8]. The availability of these data greatly facilitates research in tick biology and tick-host-pathogen interactions. Microarrays and quantitative RT-PCR are two important techniques measuring gene expression which may help in unraveling such interactions and provide insight into the complex regulatory networks behind biological processes. Output data require normalization to control for variables such as the intrinsic variability of RNA, impurities during RNA extraction, reverse transcription and PCR efficiencies [9]. A frequently used method for the accurate normalization of quantitative RT-PCR data involves the measurement of internal reference genes (also referred to as housekeeping genes). Such genes should ideally have a stable expression independent of cell or tissue type, or experimental condition. A survey of 20 papers using quantitative RT-PCR in tick research published between 2004 and 2008 shows $\beta$ actin as the most popular reference gene used for normal- ization in 19 publications, with the one remaining article employing the 18S rRNA gene. However, the presumed expression stability of these genes in ticks has never been examined and the use of a single reference gene may lead to erroneous normalization [10]. In this study, the mRNA transcript levels of nine commonly used reference genes from different functional classes: $\beta$-actin (ACTB), $\beta$-tubulin (BTUB), elongation factor $1 \alpha$ (ELF1A), glyceraldehyde 3-phosphate dehydrogenase (GAPDH), glutathione Stransferase (GST), H3 histone family 3A (H3F3A), cyclophilin (PPIA), ribosomal protein L4 (RPL4) and TATA box binding protein (TBP) were measured by quantitative RTPCR in all life stages of whole R. microplus and R. appendiculatus ticks. The results were evaluated using geNorm [10] and Normfinder [11]. Although both programs have the same aim of identifying the most stably expressed reference genes, they make use of different strategies. geNorm is a software application which determines the expression stability of reference genes by calculating a gene-stability measure $(M)$ for each gene. This measure relies on the principle that the expression ratio of two ideal reference genes is identical in all samples, regardless of the experimental condition or cell type. Pairwise variation for each combination of reference genes is determined and assigned a value for $M$, and genes with the highest $M$ value (i.e. least stable expression) are progressively eliminated until the two most stably expressed genes remain. It thus ranks the reference genes according to the similarity in expression profiles across the samples [10]. Incorporation of co-regulated reference genes will affect the outcome of this approach and care must therefore be taken in selecting candidate reference genes from different functional classes. Normfinder is an application on a model-based approach which ranks the reference genes according to the estimated intra- and intergroup expression variation. Normalization with the six most stable expressed reference genes of the Bm86 mRNA transcript levels in all life stages of $R$. microplus and R. appendiculatus was carried out with the aim to elucidate the role of antigen abundance in Bm86 vaccine susceptibility.

\section{Results \\ Quantitative RT-PCR}

The efficiencies of the quantitative RT-PCR's were uniformly high and ranged from $91 \%$ to $103 \%$, making all assays suitable for quantitative analysis (Table 1). All PCR's generated a single band and the absence of primer dimer formation was confirmed by a dissociation assay performed with each assay (results not shown). None of the primer combinations amplified cDNA synthesized from bovine blood RNA, which excludes interference with the PCR results caused by the possible presence of host RNA in fed ticks. Raw Ct values ranged from 14.8 (ACTB) to 31.0 (GST) in R. microplus and from 11.8 (ACTB) to 34.3 (GST) in R. appendiculatus (Table 2, Fig. 1 \& 2). 
Table I: Details of the quantitative RT-PCRs of Bm86 and the candidate reference genes evaluated in this study.

\begin{tabular}{|c|c|c|c|c|c|c|c|c|c|}
\hline \multirow[t]{2}{*}{ Symbol } & \multirow[t]{2}{*}{ Gene name } & \multirow[t]{2}{*}{ Function } & \multicolumn{2}{|c|}{$\begin{array}{l}\text { GenBank accession } \\
\text { number }\end{array}$} & \multirow[t]{2}{*}{ Forward primer } & \multirow[t]{2}{*}{ Reverse primer } & \multirow[t]{2}{*}{$\begin{array}{l}\text { Amplicon } \\
\text { length }\end{array}$} & \multicolumn{2}{|c|}{ Efficiency } \\
\hline & & & $R m^{a}$ & $\mathbf{R a}^{a}$ & & & & $R m^{a}$ & $R_{a^{a}}$ \\
\hline ACTB & Beta actin & $\begin{array}{l}\text { Cytoskeletal } \\
\text { structural } \\
\text { protein }\end{array}$ & AY255624 & $\underline{\text { AY254899 }}$ & $\begin{array}{l}\text { CCCATCTACGAA } \\
\text { GGTTACGCC }\end{array}$ & $\begin{array}{l}\text { CGCACGATTTCA } \\
\text { CGCTCAG }\end{array}$ & 139 bp & 102 & 98 \\
\hline Bm86 & Bm86 & Unknown & F)809946 & F]809944 & $\begin{array}{l}\text { CGTCCCGACTT } \\
\text { GACCTGC }\end{array}$ & $\begin{array}{l}\text { AGGAGCGGCTG } \\
\text { AACAGTTTG }\end{array}$ & $101 \mathrm{bp}$ & 103 & 103 \\
\hline BTUB & Beta tubulin & $\begin{array}{l}\text { Component of } \\
\text { microtubules }\end{array}$ & CKI79480 & CD781348 & $\begin{array}{l}\text { AACATGGTGCC } \\
\text { CTTCCCACG }\end{array}$ & $\begin{array}{l}\text { GCAGCCATCATG } \\
\text { TTCTTTGC }\end{array}$ & $140 \mathrm{bp}$ & 92 & 97 \\
\hline ELFIA & $\begin{array}{l}\text { Elongation } \\
\text { factor I-alpha }\end{array}$ & $\begin{array}{l}\text { Component of } \\
\text { the eukaryotic } \\
\text { translational } \\
\text { apparatus }\end{array}$ & EW679365 & CD797I49 & $\begin{array}{l}\text { CGTCTACAAGAT } \\
\text { TGGTGGCATT }\end{array}$ & $\begin{array}{l}\text { CTCAGTGGTCAG } \\
\text { GTTGGCAG }\end{array}$ & 108 bp & 100 & 92 \\
\hline GAPDH & $\begin{array}{l}\text { Glyceraldehyde- } \\
\text { 3-phosphate } \\
\text { dehydrogenase }\end{array}$ & $\begin{array}{l}\text { Oxireductase in } \\
\text { glycolysis and } \\
\text { gluconeogenesis }\end{array}$ & CKI80824 & CD791831 & $\begin{array}{l}\text { AGTCCACCGGC } \\
\text { GTCTTCCTCA }\end{array}$ & $\begin{array}{l}\text { GTGTGGTTCACA } \\
\text { CCCATCACAA }\end{array}$ & $123 \mathrm{bp}$ & 97 & 91 \\
\hline GST & $\begin{array}{l}\text { Glutathione S- } \\
\text { transferase }\end{array}$ & $\begin{array}{l}\text { Detoxification of } \\
\text { endobiotic and } \\
\text { xenobiotic } \\
\text { substrates }\end{array}$ & $\underline{\mathrm{CV} 456312}$ & CD789942 & $\begin{array}{l}\text { TACCTGGGCAA } \\
\text { GAAGCACGG }\end{array}$ & $\begin{array}{l}\text { AGAGCCCAGAG } \\
\text { CAGGTCGTTG }\end{array}$ & $98 \mathrm{bp}$ & 93 & 100 \\
\hline $\mathrm{H} 3 \mathrm{~F} 3 \mathrm{~A}$ & $\begin{array}{l}\mathrm{H} 3 \text { Histone } \\
\text { family } 3 \mathrm{~A}\end{array}$ & $\begin{array}{l}\text { Involved in } \\
\text { structure of } \\
\text { chromatin }\end{array}$ & CV442167 & CD795637 & $\begin{array}{l}\text { AAGCAGACCGC } \\
\text { CCGTAAGT }\end{array}$ & $\begin{array}{l}\text { GTAACGACGGAT } \\
\text { CTCCCTGAG }\end{array}$ & 152 bp & 92 & 95 \\
\hline PPIA & Cyclophilin & $\begin{array}{l}\text { Facilitate protein } \\
\text { folding }\end{array}$ & CV445080 & CD793819 & $\begin{array}{l}\text { CTGGGACGGAT } \\
\text { AGTAATTGAGC }\end{array}$ & $\begin{array}{l}\text { ATGAAGTTGGGG } \\
\text { ATGACGC }\end{array}$ & $133 \mathrm{bp}$ & 95 & 98 \\
\hline RPL4 & $\begin{array}{l}\text { Ribosomal } \\
\text { protein } L 4\end{array}$ & $\begin{array}{l}\text { Structural } \\
\text { component of } \\
\text { the large } 605 \\
\text { ribosomal } \\
\text { subunit }\end{array}$ & CV447629 & CD794864 & $\begin{array}{l}\text { AGGTTCCCCTG } \\
\text { GTGGTGAG }\end{array}$ & $\begin{array}{l}\text { GTTCCTCATCTT } \\
\text { TCCCTTGCC }\end{array}$ & $152 \mathrm{bp}$ & 93 & 98 \\
\hline TBP & $\begin{array}{l}\text { TATA box } \\
\text { binding protein }\end{array}$ & $\begin{array}{l}\text { Transcription } \\
\text { factor }\end{array}$ & CV4538I8 & CD780134 & $\begin{array}{l}\text { CTTGTCCTCACA } \\
\text { CACAGCCAGTT }\end{array}$ & $\begin{array}{l}\text { GTGAGCACGACT } \\
\text { TTTCCAGATAC }\end{array}$ & 122 bp & 94 & 100 \\
\hline
\end{tabular}

${ }^{a}$ Rm, R. microplus; Ra, R. appendiculatus

Table 2: Cycle threshold $\left(C_{t}\right)$ values of candidate reference genes and $B m 86$

\begin{tabular}{|c|c|c|c|c|c|c|c|c|}
\hline \multirow[t]{2}{*}{ Gene } & \multicolumn{2}{|c|}{$C_{t}$ Range } & \multicolumn{2}{|c|}{$\mathbf{C}_{\mathbf{t}}$ Min. } & \multicolumn{2}{|c|}{$C_{t} \operatorname{Max}$} & \multicolumn{2}{|c|}{ mean $C_{t} \pm$ s.e.m. } \\
\hline & $R m^{a}$ & $\operatorname{Ra}^{a}$ & $R m^{a}$ & $\mathbf{R a}^{a}$ & $R m^{a}$ & $\operatorname{Ra}^{a}$ & $R m^{a}$ & $\mathbf{R a}^{a}$ \\
\hline ACTB & 5.62 & 5.92 & 14.85 & 11.80 & 20.47 & 17.72 & $16.48 \pm 0.25$ & $15.59 \pm 0.24$ \\
\hline BTUB & 4.01 & 4.74 & 19.57 & 19.22 & 23.58 & 23.96 & $21.00 \pm 0.16$ & $21.76 \pm 0.24$ \\
\hline ELFIA & 2.36 & 3.90 & 16.36 & 15.34 & 18.72 & 19.24 & $17.29 \pm 0.12$ & $17.01 \pm 0.17$ \\
\hline GAPDH & 4.39 & 3.47 & 21.67 & 20.56 & 26.06 & 24.04 & $23.02 \pm 0.20$ & $22.29 \pm 0.17$ \\
\hline GST & 10.77 & $|3.4|$ & 20.28 & 20.90 & 31.05 & 34.31 & $24.27 \pm 0.51$ & $27.22 \pm 0.67$ \\
\hline $\mathrm{H} 3 \mathrm{~F} 3 \mathrm{~A}$ & 4.03 & 4.69 & 16.35 & 17.68 & 20.39 & 22.36 & $18.74 \pm 0.15$ & $19.90 \pm 0.20$ \\
\hline PPIA & 4.38 & 3.90 & 17.92 & 17.98 & 22.30 & 21.88 & $\mid 9.31 \pm 0.20$ & $19.91 \pm 0.20$ \\
\hline RPL4 & 3.09 & 3.83 & 17.68 & 17.39 & 20.77 & 21.22 & $18.82 \pm 0.12$ & $18.87 \pm 0.15$ \\
\hline TBP & 2.27 & 4.28 & 25.74 & 25.70 & 28.01 & 29.98 & $27.01 \pm 0.09$ & $26.99 \pm 0.20$ \\
\hline Bm86 & 10.38 & 7.56 & 21.28 & 19.86 & 31.66 & 27.42 & $24.05 \pm 0.40$ & $22.85 \pm 0.44$ \\
\hline
\end{tabular}

${ }^{a} \mathrm{Rm}, \mathrm{R}$. microplus; Ra, R. appendiculatus 


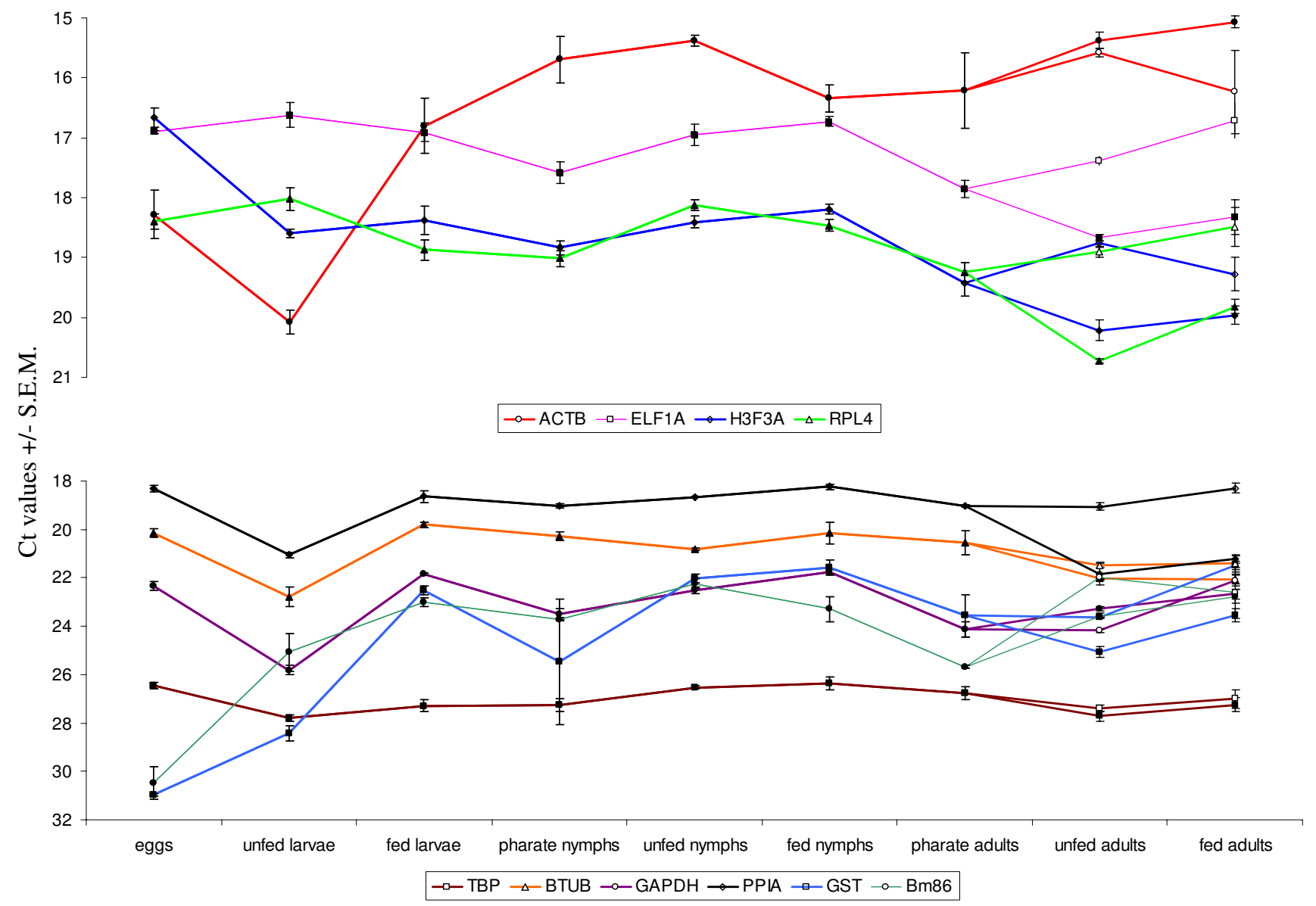

Figure I

Bm86 and control gene expression during all life stages of $\boldsymbol{R}$. microplus. Ct values represent mean $+/$ - SEM from three biological replicates. The $\mathrm{Ct}$ values of samples from adult females are indicated with an open symbol, $\mathrm{C} t$ values from adult males with a closed symbol. Note that the y-axis differs in the two panels: highly expressed genes are shown in the top panel, moderately expressed genes in the bottom panel.

GAPDH, GST and TBP were expressed at low levels in both tick species with median $\mathrm{Ct}$ values above 22 cycles. The smallest Ct variation between all samples of $R$. microplus was exhibited by TBP (2.27) and by GAPDH (3.42) in $R$. appendiculatus. GST showed the most variable expression between all samples for both tick species; 10.77 in $R$. microplus and 13.41 in R. appendiculatus.

\section{geNorm and Normfinder analysis}

The gene expression stability of nine candidate reference genes over the life cycle of $R$. microplus and $R$. appendiculatus was analyzed using the geNorm and Normfinder software applications (Table 3). The geNorm approach identified ELF1A and RPL4 as the best pair of reference genes over the life cycle of both $R$. microplus and $R$. appendiculatus, as well as in a combined analysis of all samples from both species. Normfinder ranked these genes as second and third best in R. microplus and R. appendiculatus with TBP and GAPDH being indicated as the best reference gene, respectively. A combined analysis of both species by Normfinder ranked ELF1A as best reference gene followed by GAPDH, TBP, PPIA, RPL4, H3F3A, BTUB, ACTB and GST. GST and ACTB were identified as the least stable genes in all groups by both methods.

To determine the minimum number of reference genes necessary for accurate normalization, calculation of the pairwise variation $\left(V_{n / n+1}\right)$ was performed by geNorm. The lowest $V$ values were found to be 0.131 for $V_{5 / 6}$ in $R$. microplus and 0.168 for $V_{7 / 8}$ in $R$. appendiculatus. Combined analysis of both tick species yielded a lowest $V$ value of 0.156 at $V_{6 / 7}$ (Fig. 3).

\section{Bm86 and Ra86 sequence analysis}

One sequence for Bm86 (Mozambique) and two sequences from the Bm86 homologue of $R$. appendicula- 


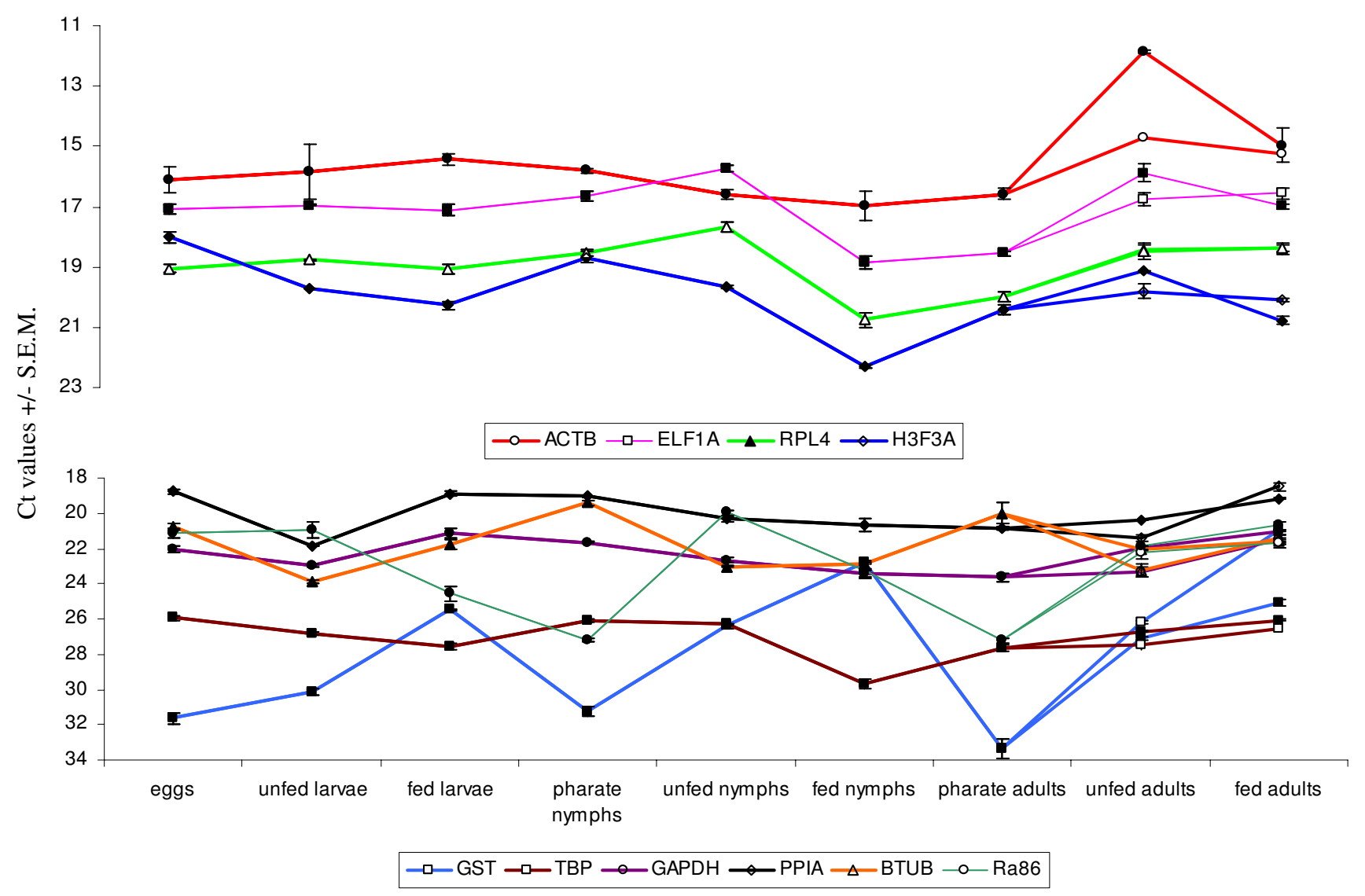

Figure 2

Ra86 and control gene expression during all life stages of $\boldsymbol{R}$. appendiculatus. Ct values represent mean $+/-\mathrm{SEM}$ from three biological replicates. The $\mathrm{C} t$ values of samples from adult females are indicated with an open symbol, $\mathrm{C} t$ values from adult males with a closed symbol. Note that the $y$-axis differs in the two panels: highly expressed genes are shown in the top panel, moderately expressed genes in the bottom panel.

Table 3: Candidate reference genes ranked according to their expression stability as calculated by the Normfinder and geNorm programs.

\begin{tabular}{|c|c|c|c|c|c|}
\hline \multicolumn{2}{|c|}{ R. microplus } & \multicolumn{2}{|c|}{ R. appendiculatus } & \multicolumn{2}{|c|}{ R. microplus and $R$. appendiculatus } \\
\hline geNorm & Normfinder & geNorm & Normfinder & geNorm & Normfinder \\
\hline \multirow[t]{2}{*}{ ELFIA and RPL4 $(0.301)$} & TBP $(0.400)$ & ELFIA and RPL4 (0.37I) & GAPDH (0.359) & ELFIA and RPL4 (0.376) & ELFIA (0.477) \\
\hline & ELFIA (0.459) & & ELFIA $(0.424)$ & & GAPDH $(0.521)$ \\
\hline H3F3A (0.559) & RPL4 $(0.463)$ & TBP $(0.614)$ & RPL4 $(0.48 I)$ & $\operatorname{TBP}(0.619)$ & TBP $(0.549)$ \\
\hline TBP $(0.656)$ & BTUB $(0.485)$ & GAPDH $(0.764)$ & PPIA $(0.580)$ & H3F3A (0.778) & PPIA $(0.555)$ \\
\hline BTUB $(0.77 \mathrm{I})$ & PPIA $(0.5 \mid 2)$ & $\mathrm{H} 3 \mathrm{~F} 3 \mathrm{~A}(0.856)$ & TBP $(0.583)$ & PPIA (0.926) & RPL4 (0.563) \\
\hline PPIA (0.824) & $\mathrm{H} 3 \mathrm{~F} 3 \mathrm{~A}(0.577)$ & PPIA (0.959) & H3F3A (0.709) & GAPDH $(0.995)$ & H3F3A (0.623) \\
\hline GAPDH $(0.940)$ & GAPDH (0.649) & ACTB (1.097) & ACTB $(0.720)$ & BTUB (I.074) & BTUB $(0.680)$ \\
\hline ACTB (I.159) & ACTB (0.952) & BTUB (I.203) & BTUB (0.852) & ACTB (1.259) & ACTB $(0.962)$ \\
\hline GST $(1.5 \mid 2)$ & GST (I.450) & GST (I.818) & GST $(2.128)$ & GST (I.795) & GST (I.899) \\
\hline
\end{tabular}

The candidates are listed with decreasing expression stability from top to bottom. Average expression stability values are shown between parentheses. 


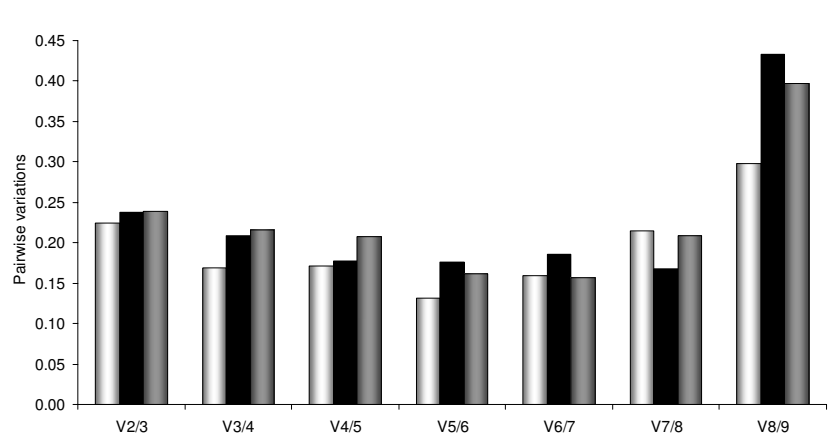

Figure 3

Optimal number of control genes for normalization as determined by geNorm for R. microplus (white bars), $R$. appendiculatus (black bars) and in a combined analysis (grey bars).

tus, Ra86-1 and Ra86-2, were obtained by 3'RACE with degenerate primer Ra86-F, which is located one amino acid downstream of the signal peptide of $\mathrm{Bm} 86$. The open reading frame (ORF) of the Bm86 (Mozambique) nucleotide sequence is $1890 \mathrm{bp}$, coding for a protein of 629 amino acids which is $96.5 \%$ identical to the $\mathrm{Bm} 86$ Yeerongpilly reference strain (Australia) with similar structural properties. The 22 amino acid gap reported previously in a second Bm86 (Mozambique) sequence (GenBank accession number ABY58968) was not detected in any of the five sequenced clones. Both $R$. appendiculatus sequences contain a 1905 bp-long ORF which encodes for 634 amino acids. The alleles differ by 45 nucleotides of which 13 are silent mutations and 32 result in a change in the deduced amino acid sequence of the protein [see Additional file 1]. The identity of the amino acid sequence of Ra86-1 and Ra86-2 are $72.9 \%$ and $73.8 \%$ with the Bm86 proteins of R. microplus (Australia) and $73.7 \%$ and $74.6 \%$ with $R$. microplus (Mozambique) respectively. A comparison between the amino acid sequence of Ra86 and Bm86 shows that Ra86 contains the same Epidermal Growth Factor (EGF)-like domains as Bm86 [12]. These domains are also present in Ba86, Bd86 and Haa86, the Bm86 homologues of $R$. annulatus, $R$. decoloratus and $H y$. a. anatolicum respectively (Fig. 4). The Ra86 sequences contain 5 potential sites for N-linked glycosylation (AsnXaa-Ser/Thr) and Ra86-2 has 1 potential O-glycosylation site (Ser/Thr). Both Ra86-1 and Ra86-2 are predicted to contain a glycosylphosphatidylinositol (GPI) modification site at position 613 (serine), which provides linkage of the molecule to the cell membrane. The presence of a GPI anchor is a common feature found in all ixodid tick Bm86 homologues characterized thus far. Western Blot analysis showed that ovine Bm86 antiserum recognized bands of the expected Ra86 protein size in the isolated midguts from partially fed $R$. appendiculatus females whereas serum from a sheep vaccinated with adjuvant only did not (Fig. 5).

\section{Bm86/Ra86 expression analysis}

The expression profile of Bm86/Ra86 mRNA (referred to as Bm86 from this point onwards for convenience) in both $R$. microplus and $R$. appendiculatus was obtained by normalizing its expression with six reference genes that ranked highest in the geNorm and Normfinder analysis of the combined $R$. microplus and $R$. appendiculatus samples: ELF1A, GAPDH, H3F3A, PPIA, RPL4 and TBP (Fig. 6). In eggs of $R$. microplus, Bm86 expression was detected at low levels in eggs 4 and 10 days after initiation of the oviposition (p.o.: post oviposition) and increased by three-fold in eggs collected 15 days p.o. This formed the start of a rapid increase in the expression of Bm86 in the third trimester of the embryogenesis to levels similar to that found in unfed larvae. Bm86 expression decreased with feeding and molting in the immature life stages, with the lowest expression found in the pharate life stages. The decrease of Bm86 expression levels following feeding of immatures was significantly more pronounced in the larvae and nymphs of $R$. appendiculatus compared to $R$. microplus where a more continuous expression pattern was observed during the life cycle with less dramatic variation. The expression level of Bm86 in adults did not differ significantly between males and females of both species.

\section{Discussion}

To minimize RT-PCR specific errors and correct for sample-to-sample variation in order to make a comparison of the Bm86 expression profiles from $R$. microplus and $R$. appendiculatus possible, appropriate normalization is required. The use of reference genes is most frequently applied to normalize the mRNA fraction, but validation of the expression stability of such genes in ticks has not been reported until now. ACTB is the most commonly used reference gene in tick research, but recent findings in mammals revealed that this gene and other commonly used 'classical' reference genes such as GAPDH may be inappropriate for use as a reference gene because of their variability under experimental conditions $[9,13]$.

The ideal reference gene should be expressed at a constant level in the tissue(s) of interest at all stages of development and be unaffected by the specific experimental treatment being examined. However, no such universal reference gene has yet been identified and probably does not exist [9-11]. Normalization with multiple selected reference genes has been proposed as an alternative to overcome this problem and several tools to evaluate the expression stability of candidate reference genes have been developed. In this study, two of these tools, the geNorm [10] and Normfinder [11] programs, were employed to evaluate the expression stability of nine selected candidate reference genes.

Besides the two 'classical' reference genes ACTB and GAPDH, other candidate reference genes evaluated in this 


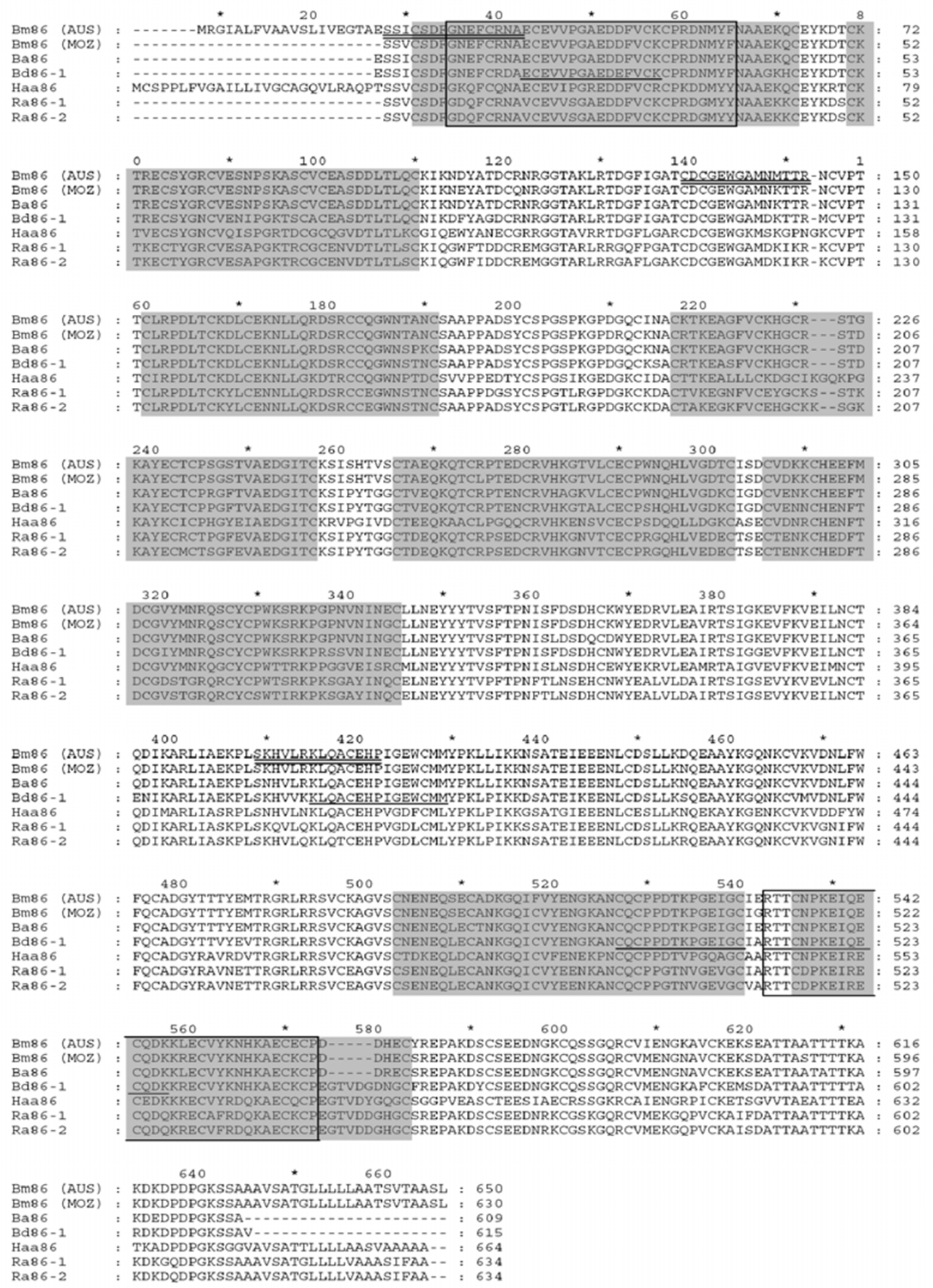

\section{Figure 4}

Alignment of the amino acid sequences of the Bm86 homologues from ticks for which Bm86 vaccine efficiency has been documented: Bm86 AUS (Australian strain) (AAA30098), Bm86 MOZ (Mozambique strain) (FJ809946), Ba86 (ABY58969), Bd86 (ABG2 I I I I), Haa86 (AAL36024), Ra86-I (FJ809944) and Ra86-2 (FJ809945). Cross reactive linear B-cell epitopes mapped using pin-coupled peptides by Odongo et al. [5] are boxed, the regions identified using biotin-coupled peptides by the same authors are underlined. Three synthetic peptides used by Patarroyo et al. [33] which induced an immune response against $R$. microplus are double underlined and EGF-like domains fitting the

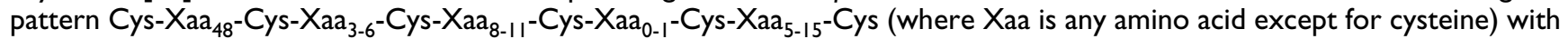
5 or 6 cysteine residues are shaded grey. The phenylalanine at position 507 of Bm86 AUS was predicted to be a cysteine when the sequence of a second cDNA clone from a separate library was determined by Rand et al. [12]. 
study were from different functional classes and were selected based on their reported expression stability in other organisms and their presence in the EST libraries of R. microplus and R. appendiculatus [6-8]. RPL4 for instance was among the thirteen ribosomal proteins which were ranked in the top 15 of most stable expressed reference genes in a meta-analysis performed on a large dataset of human gene arrays [13]. Other ribosomal proteins were not included in this study to prevent bias in the ranking of the reference genes due to correlated expression of proteins belonging to the same functional class.

The outcome of the gene stability evaluation differed between the programs used, which is not surprising in light of the different algorithms they employ. Only ELF1A was consistently ranked first or second by both programs and is suitable for use as a reference gene under the conditions described here. RPL4 is consistently ranked as the most stable expressed gene together with ELF1A by geNorm but not by Normfinder. Since both ELF1A and RPL4 play a role in protein translation, co-regulation cannot be ruled out and this may have affected the outcome of the geNorm analysis. Normfinder is less sensitive to the incorporation of co-regulated genes since it focuses on the intra- and intergroup variation in selecting the most stable expressed genes [11]. This may altogether explain the discordance in ranking of RPL4 between the geNorm and Normfinder programs. GST turned out to be the least stable gene in all conducted analyses (Table 3). GST is known to be differentially expressed under different conditions [14-16] and so could be expected to perform poorly as a reference gene. Of the 'traditional' reference genes, ACTB was ranked among the least stable genes by both methods whereas GAPDH was ranked first in the Normfinder analysis of the R. appendiculatus life stages. This is a direct result of the small Ct variation observed in the GAPDH expression in this species, which also explains the high ranking of TBP in the Normfinder analysis of the $R$. microplus life stages where this gene showed the least $\mathrm{Ct}$ variation over all samples.

Analysis of the pairwise variation $\left(V_{n / n+1}\right)$ of the samples by geNorm returned values slightly lower or higher than the arbitrarily chosen threshold of 0.15 [10], reflecting the heterogeneous nature of the analyzed whole tick samples which varied from egg to feeding adults. A direct consequence is the need of using a larger number of reference genes for optimal normalization. To be able to compare the Bm86 mRNA expression between all life stages of $R$. microplus and R. appendiculatus, normalization with six reference genes: ELF1A, RPL4, TBP, H3F3A, PPIA and GAPDH was conducted. These reference genes were evaluated as being the most stable by both geNorm and Normfinder in a combined analysis of all samples from both tick species and returned the lowest pairwise variation value in the geNorm analysis $\left(V_{6 / 7}=0.156\right)$.
The protein sequence of the Bm86 gene from the Mozambique $R$. microplus strain was highly identical to previously reported Bm86 sequences from Australia and South America and shared a maximum identity of $97.0 \%$ with the Bm86 sequence from a $R$. microplus strain from central Brazil (GenBank accession number ACA57829). A second Bm86 sequence isolated from the viscera of partially fed females originating from the same Mozambique tick colony (GenBank accession number ABY58968) contains a 22 amino acid gap which was not present in the Bm86 sequence identified in this study [17]. This sequence was not found in any of the five sequenced clones and may be less abundant, have been the result of alternative splicing or represent an allele which was lost in the R. microplus tick population since the source material was collected several generations earlier. The presence of $\mathrm{Bm} 86$ alleles within the same tick population has been previously reported [18]. Two alleles, Ra86-1 and Ra86-2, were also found to be transcribed in the midgut of $R$. appendiculatus females. The ORFs were similar in size but the alleles differed by 32 amino acids. These differences do not appear to have a striking effect on the main properties of these proteins since both Ra86-1 and Ra86-2 are predicted to contain a GPI-anchor and contain EGF-like domains similar to those found in Bm86 (Fig. 4), but Ra86-2 does have a single potential $O$-glycosylation site which is absent from Ra86-1. Since Boophilus species were recently synonymized with the Rhipicephalus genus [19], it is not surprising that the Ra86 protein shows a higher amino acid sequence identity with $\mathrm{Bm} 86(\sim 73 \%)$ compared to the Haa 86 protein, the Bm86 homologue from the two-host tick Hy. anatolicum (65\%). However, feeding of $H y$. anatolicum on cattle vaccinated with a recombinant $\mathrm{Bm} 86$ vaccine does result in a deleterious effect against this tick species which is not seen in $R$. appendiculatus [4]. Since Western Blot analysis showed that ovine Bm86 antisera does indeed recognize R. appendiculatus proteins (Fig. 5), other biological factors such as conformational epitopes, amount of blood/antibodies ingested, or antigen abundance may play a role in the biology of $\mathrm{Bm} 86$ vaccine susceptibility. To investigate the latter hypothesis, the $\mathrm{Bm} 86$ and Ra86 transcript levels were measured throughout the life cycle of both tick species feeding on the same host by quantitative RT-PCR using a single primer pair which amplifies all known alleles of Bm86 and Ra86.

The normalized Bm86 mRNA expression levels were monitored in various stages of embryonic development in R. microplus and were found to increase exponentially during the last 9 days prior to hatching, simultaneous with the development of the midgut in embryos which takes place in the third trimester of embryogenesis in ixodid ticks [20,21] (Fig. 6). At day 20 p.o. expression levels of Bm86 were 18 (8-40) times higher in $R$. appendiculatus eggs compared to R. microplus eggs, a difference that might in part be explained by a more advanced egg development 


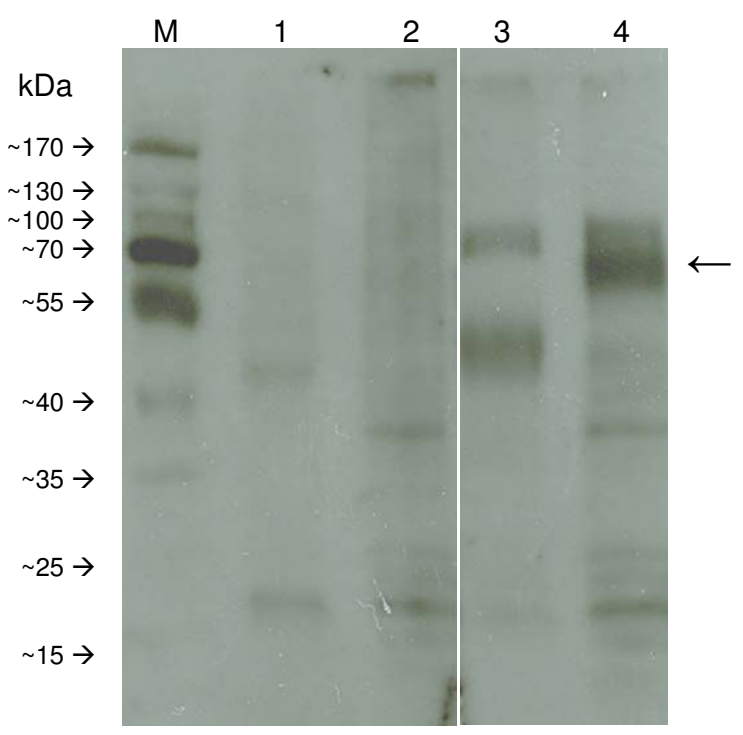

\section{Figure 5}

Immunodetection of Ra86 by Western Blot analysis using ovine Bm86 antiserum. Lanes I and 2: $R$. microplus and $R$. appendiculatus midgut proteins probed with control serum from a sheep vaccinated with adjuvant only, lanes 3 and 4: $R$. microplus and $R$. appendiculatus midgut proteins probed with ovine Bm86 antisera. The arrow on the right indicates the $\mathrm{Bm} 86$ and $\mathrm{Ra} 86$ proteins.

in $R$. appendiculatus eggs as they were noted to hatch one day earlier than eggs from $R$. microplus. The same large difference in Bm86 expression level was also observed in unfed larvae and nymphs where Bm86 expression levels were approximately tenfold higher in $R$. appendiculatus immatures in anticipation of a blood meal compared to unfed $R$. microplus larvae and nymphs. It should be noted that all samples were collected at single well defined points from each life stage and fluctuations possibly occurring during these life stages could therefore have been missed. The Bm86 expression decreased significantly during feeding and particularly during molting in $R$. appendiculatus, a decrease which was present in $R$. microplus nymphs as well but to a far lesser extent. Bm86 expression levels of adults from both species were similar and so the total amount of Bm86 expressed during blood feeding and exposure to the host immune system may be comparable between adults of the two species, assuming that the expression profile of $\mathrm{Bm} 86 \mathrm{mRNA}$ is indicative for the amount of expressed Bm86 protein. If so, differences in Bm86 vaccination susceptibility could perhaps be sought in the prolonged exposure to imbibed blood and the host immune system of $R$. microplus which is adapted for continuous development on one host compared to the threehost tick R. appendiculatus. The latter has a longer 'recovery' period during molting at which time no or very little Bm86 is expressed. Hence little reaction between ingested antibodies and the Bm86 protein would be expected to occur. However, effects of vaccination with $\mathrm{Bm} 86$ are predominantly seen in adults of $R$. microplus [22]. This is corroborated by the fact that if $R$. microplus are raised to the stage of unfed adults on non-vaccinated cattle, then transferred to either vaccinated sheep [23] or to an in-vitro feeding system using blood from vaccinated cattle [22], strong vaccine effects are seen. As mentioned earlier, this effect is not seen in $R$. appendiculatus adults feeding on cows vaccinated with Bm86 [4,5], although both $R$. microplus and $R$. appendiculatus have comparable Bm86 expression levels in both unfed and fed adults.

Although the nomenclature used to distinguish the various cell types present in the midgut of ticks is not unanimous, the midgut is thought to consist of the following epithelial cell types: stem cells, also referred to as undifferentiated reserve cell [24] or replacement cell [25], various stages of digest cells, secretory cells and albeit controversial, a basophilic cell type [26-28]. The digest cells are thought to derive from the stem cells and transform from a prodigest cell type to a sessile digest cell following the absorption of blood meal haemoglobin. Sessile cells may detach from the basal lamina into the gut lumen, thus becoming detached or motile digest cells. Upon release of their hematin granules and other indigestible products into the lumen they are termed spent or degenerating digest cells [27]. Exhausted digest cells are replaced by consecutive cycles of growth and differentiation from undifferentiated cells so multiple generations of a digest cell type may be present at the same time, which has led to some confusion in the interpretation of these events [29]. While it has been reported that the $\mathrm{Bm} 86$ protein is located predominantly on the microvilli surface of digest cells, the exact cell type could not be determined for technical reasons [2]. The high Bm86 expression levels found in eggs in the third trimester of embryogenesis and unfed larvae suggest that stem cells and/or prodigest cells are expressing Bm86 protein as well. This would be in concordance with the hypothesized function of $\mathrm{Bm} 86$ in the regulation of cell growth based on its sequence and structural homology to epidermal growth factor precursors [30] and the greater abundance of Bm86 towards the apical tips of gut digest cells associating it with a regulatory role in the apical growth [2]. Since antibodies from vaccination sera will bind to tick gut cells and inhibit their endocytotic function, involvement of Bm86 in endocytosis of the blood meal seemed possible. However, the inhibition of endocytosis was suggested to be an indirect effect of Bm86 antibodies binding to the Bm86 protein [22]. The low levels of Bm86 expression in feeding and pharate immature ticks and comparable expression levels between unfed and feeding adults make a role for $\mathrm{Bm} 86$ in endocytosis more unlikely since the expression of proteins involved in endocytosis is expected to increase during the uptake of a bloodmeal. 


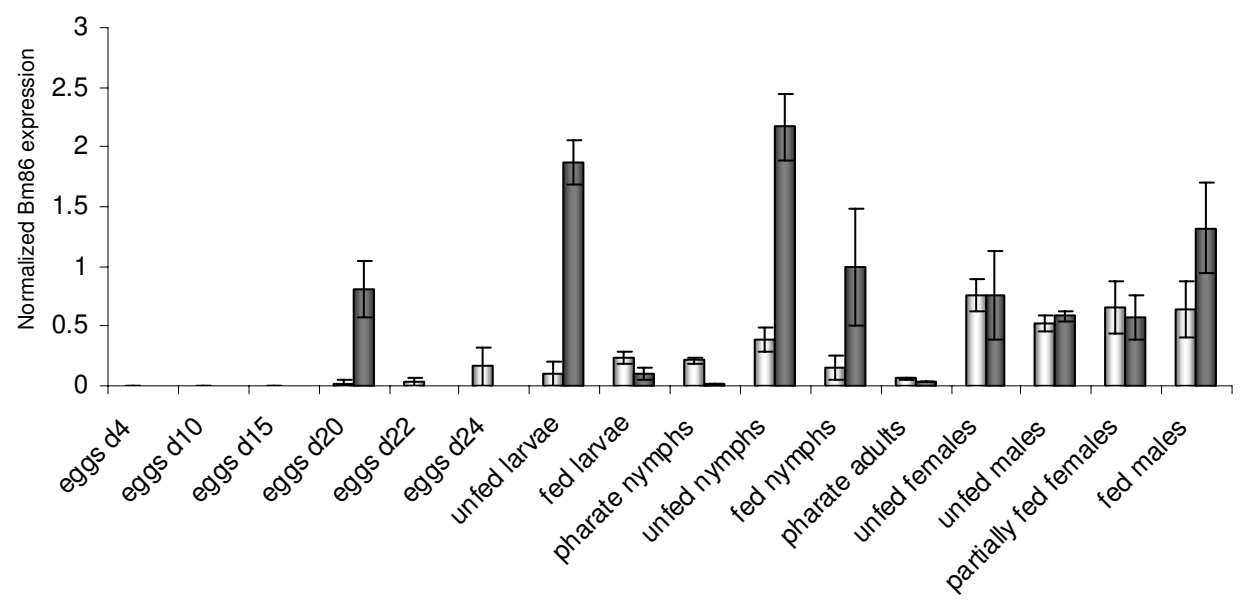

\section{Figure 6}

Bm86 (white bars) and Ra86 (grey bars) expression levels in all life stages, normalized against the six most stably expressed reference genes in both $R$. microplus and $R$. appendiculatus: ELF IA, GAPDH, H3F3A, PPIA, RPL4 and TBP. Bars represent the $95 \%$ confidence interval of the normalized expression. Eggs of $R$. appendiculatus were only collected at day 20 after the start of oviposition and expression levels from other time points of embryogenesis are therefore missing.

\section{Conclusion}

Nine candidate reference genes from different functional classes were identified in the EST databases of $R$. microplus and $R$. appendiculatus and their expression stability throughout the life cycle of these two tick species was evaluated. ELF1A was found to be the most stable expressed gene in both tick species following analysis by both the geNorm and Normfinder software applications, GST showed the least stability. The six most stable expressed genes were used for normalization of the expression profile of the tick-protective antigen Bm86 for both R. microplus and $R$. appendiculatus. This expression profile revealed a more continuous Bm86 antigen abundance in $R$. microplus throughout its one-host life cycle compared to the three-host tick $R$. appendiculatus where large variations were observed between the different life stages. The observed differences in Bm86 expression profile between the two species alone can not adequately explain the lack of a Bm86 vaccination effect in $R$. appendiculatus.

\section{Methods}

\section{Experimental animals}

One Holstein-Friesian calf 6 months of age (\#1471) was used. The animal had no previous exposure to ticks. All tick feedings were approved by the Animal Experiments Committee (DEC) of the Faculty of Veterinary Medicine, Utrecht University (DEC No. 0111.0807).

\section{RNA isolation from bovine blood}

Total RNA was isolated from 2 ml blood from calf \#1471 prior to the tick feedings using the RNeasy mini kit (Qiagen, Venlo, the Netherlands) according to the manufacturer's protocol.

\section{Ticks and tick feeding}

R. microplus ticks originating from Mozambique were provided by ClinVet International (Pty), Bloemfontein, South Africa and $R$. appendiculatus ticks originating from South Africa were provided by the Onderstepoort Veterinary Institute, Onderstepoort, South Africa. Both species were subsequently maintained on experimental animals at the tick rearing facility of the Utrecht Centre for Tickborne Diseases (UCTD) for several generations. Free-living stages were kept at $20^{\circ} \mathrm{C}$ at $95 \%$ relative humidity. Ticks from all life stages of $R$. appendiculatus and unfed larvae of $R$. microplus were available at the start of the experiment. Circular patches used for tick feeding with an inner diameter of $120 \mathrm{~mm}$ and sewn to an open cotton bag were glued to the shaved back of the calf using Pattex ${ }^{\circledR}$ contact glue (Henkel Nederland, Nieuwegein, the Netherlands). The scheme shown in Table 4 was used for tick feedings. This schedule allowed for the synchronous feeding of all life stages from both tick species in separate patches on the same animal, minimizing possible variations in tick gene expression due to external (e.g. host or environmental) factors.

\section{RNA isolation}

For the isolation of total RNA from eggs and unfed larvae, triplicate pools of $100 \mathrm{mg}$ eggs or larvae were homogenized in $1 \mathrm{ml}$ TRIzol reagent using a Potter-Elvejhem glass/Teflon homogenizer. Other whole tick samples were homogenized in $1 \mathrm{ml}$ TRIzol reagent using an ultra-turrax homogenizer (IKA werke GmbH \& Co., Staufen, Germany), again in triplicate. All samples were further homogenized by passage through 24 - and 27-gauge needles and centrifuged at $12,000 \mathrm{~g}$ at $4^{\circ} \mathrm{C}$ for $10 \mathrm{~min}$ to 
remove insoluble material after which and the supernatant was frozen at $-80^{\circ} \mathrm{C}$ until RNA extraction. Total RNA was isolated and treated with DNase I (Fermentas GmbH, St. Leon Rot, Germany) prior to purification using the Nucleospin RNA II kit (Machery-Nagel, Düren, Germany), all in accordance with the manufacturer's protocols. Sample concentrations and purity were determined with a NanoDrop ND-1000 spectrophotometer (NanoDrop Technologies, Wilmington, DE, USA) at $260 \mathrm{~nm}$ (A260) wavelength. Only samples with A260/A280 and A260/A230 ratios between 1.8 and 2.2 were included in subsequent analyses. Lack of genomic DNA contamination was confirmed by PCR amplification of RNA samples followed by electrophoresis on a $1 \%$ agarose gel.

\section{Rapid amplification of 3'cDNA ends (3'-RACE), cloning and sequencing of the Bm86 and Ra86 gene}

1 thousand ng of total RNA isolated from the midguts of partially fed R. microplus (Mozambique) and R. appendiculatus (South Africa) females was used to synthesize firststrand cDNA using SuperScript III (Invitrogen) following the manufacturer's instruction using a 3'-RACE anchor primer containing a poly-T sequence [5'-GCTATCATTACCACAACACTCT $\left._{(18)}(\mathrm{AGC})(\mathrm{AGCT})-3^{\prime}\right]$. The Bm86 orthologues were subsequently PCR amplified from this cDNA using degenerate primer Ra86-F [5'TCATC(CT)(AG)T(CT)TGCTCTGACTTCGG-3'] and a 3'RACE anchor primer [5'-GCTATCATTACCACAACACTC$\left.3^{\prime}\right]$. The resulting PCR products were purified using the Nucleospin Extract kit (Machery-Nagel), cloned into the pGem-T easy vector (Promega) and five clones of each product were sequenced by Baseclear, Leiden, the Netherlands. Quantitative RT-PCR primers amplifying both Bm86 and Ra86 were designed and synthesized as described above, based upon the available sequences (Table 1). The sequences of Ra86-1, Ra86-2 (South Africa) and Bm86 (Mozambique) have been submitted to GenBank and can be retrieved under accession numbers

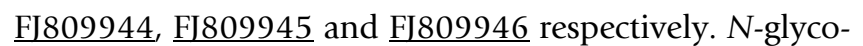
sylation and $O$-glycosylation of the deduced Ra86 protein sequence was predicted by the NetNGlyc 1.0 http:// www.cbs.dtu.dk/services/NetNGlyc/ and NetOGlyc 3.1 http://www.cbs.dtu.dk/services/NetOGlyc/ servers of the Center for Biological Sequence Analysis (CBS), Technical University of Denmark. Potential GPI-anchor sites were predicted using the online big-PI predictor tool [31] http:/ /mendel.imp.ac.at/gpi/gpi server.html.

\section{Identification of reference genes}

Protein sequences from a number of potential candidate reference genes from Drosophila melanogaster or Ceanorhabditis elegans were used for a tblastn search among the nr and the expressed sequence tag (EST) databases of $R$. microplus and $R$. appendiculatus. The sequences which were found for beta-actin (ACTB), $\beta$-tubulin (BTUB), elonga- tion factor $1 \alpha$ (ELF1A), glyceraldehyde 3-phosphate dehydrogenase (GAPDH), glutathione S-transferase (GST), H3 histone family 3A (H3F3A), cyclophilin (PPIA), ribosomal protein L4 (RPL4) and TATA box binding protein (TBP) were subsequently aligned using ClustalW http:// www.ebi.ac.uk/clustalw/, generated in BioEdit http:// www.mbio.ncsu.edu/BioEdit/bioedit.html. Non-degenerate primers were designed using the NetPrimer software application http://www.premierbiosoft.com/netprimer/ and synthesized by Isogen Life Science, IJsselstein, the Netherlands. Accession numbers and main function of each evaluated reference gene are shown in Table 1.

\section{Gene expression analysis}

cDNA was synthesized from 500 ng of DNA-free RNA isolated from bovine blood and all consecutive life stages of $R$. microplus and R. appendiculatus: eggs, unfed larvae, feeding larvae, pharate nymphs, unfed nymphs, feeding nymphs, pharate adults, unfed males/females and feeding males/females using the iScript cDNA synthesis kit (BioRad, Veenendaal, the Netherlands) according to the manufacturer's directions and stored at $-20^{\circ} \mathrm{C}$ until use in quantitative RT-PCR. A quantitative RT-PCR assay using $\mathrm{SYBR}^{\circledR}$ green detection was designed and optimized for the transcription profiling of nine commonly used reference genes (Table 1). Real-time analysis was carried out on an iCycler thermal cycler (Bio-Rad). RT-PCR amplification mixtures $(25 \mu \mathrm{l})$ contained cDNA generated from $5 \mathrm{ng}$ of RNA template, $12.5 \mu \mathrm{l}$ iQ SYBR green Supermix (Bio-Rad) and $400 \mathrm{nM}$ forward and reverse primer. The cycling conditions comprised a 5 min denaturation and polymerase activation step at $95^{\circ} \mathrm{C}, 40$ cycles of $95^{\circ} \mathrm{C}$ for $10 \mathrm{~s}, 60^{\circ} \mathrm{C}$ for $30 \mathrm{~s}$ and $72^{\circ} \mathrm{C}$ for $30 \mathrm{~s}$. Upon completion of the amplification program, a dissociation analysis $\left(52^{\circ} \mathrm{C}-95^{\circ} \mathrm{C}\right)$ was performed to determine the purity of the PCR amplicons. To estimate amplification efficiencies, a standard curve was generated for each primer pair based on known quantities of cDNA for both $R$. microplus and $R$. appendiculatus (10-fold serial dilutions corresponding to cDNA transcribed from $50 \mathrm{ng}$ to $0.05 \mathrm{ng}$ of total RNA in triplicate) and analyzed using the iQ 5 software (Bio-Rad). All assays included this standard curve, a no-template control and each of the test cDNAs. Primers, amplicon lengths and PCR efficiencies are indicated in Table 1. Raw Ct values were transformed to quantities using the comparative Ct method and specific PCR efficiencies. These quantities were converted to an input file format suitable for subsequent analysis by the geNorm or Normfinder Excel applications which were downloaded from http:// medgen.ugent.be/ jjvdesomp/genorm/ and http:// www.mdl.dk/publicationsnormfinder.htm respectively. Only the egg samples collected at day 20 from R. appendiculatus and $R$. microplus were included in the selection of reference genes using geNorm and Normfinder. The Bm86 expression was measured on the same cDNA sam- 
ples as used for the reference gene analysis but included additional $R$. microplus egg samples collected at days 4,10 , 15,22 and 24 post oviposition. The Bm86 expression levels were normalized using the geometric mean of selected reference gene quantities in Microsoft Excel following the guidelines described in the geNorm manual [32] and the 95\% confidence interval was calculated. Differential gene expression was considered significant when the 95\% confidence interval of the mean normalized expression levels did not overlap (equivalent to $\mathrm{P}<0.05$ ).

\section{Protein isolation and Western Blot}

Midguts from partially fed females were dissected in a drop of ice-cold phosphate buffered saline (PBS) using a sterile scalpel and watchmaker forceps under a stereo microscope. The midguts of three females from each species were pooled in a tube with $1 \mathrm{ml}$ washing buffer [10 $\mathrm{mM}$ Tris, $\mathrm{pH} 7.4 ; 10 \mathrm{mM} \mathrm{NaCl} ; 1 \times$ complete mini protease inhibitor cocktail (Roche Applied Science, Almere, the Netherlands)] and homogenized by passing the tissues through a $22 \mathrm{G}$ needle coupled to a $2 \mathrm{ml}$ syringe followed by a similar passage using a $27 \mathrm{G}$ needle. The homogenized samples were then centrifuged at $4{ }^{\circ} \mathrm{C}$ for $30 \mathrm{~min}$ at $15,000 \mathrm{~g}$, followed by a similar second wash. The final pellet was resuspended in $200 \mu$ of a sample buffer [62,5 mM Tris-HCl, pH 6.8; 2\% SDS; $10 \%$ glycerol; $1 \times$ complete mini protease inhibitor (Roche Applied Science)] and boiled at $100^{\circ} \mathrm{C}$ for $5 \mathrm{~min}$. The suspension was centrifuged as described above and the protein concentra- tion of the supernatant was measured using a Pierce BCA protein assay kit (Thermo Fisher Scientific, Etten-Leur, the Netherlands) and the Nanodrop ND-1000 spectrophotometer. Five $\mu \mathrm{g}$ of midgut proteins were separated on a $10 \%$ SDS-PAGE gel and transferred electrophoretically onto Hybond C nitrocellulose membranes (GE Healthcare, Diegem, Belgium). The membranes were blocked overnight at $4{ }^{\circ} \mathrm{C}$ with $2 \%$ fish gelatin (Sigma-Aldrich, Zwijndrecht, the Netherlands) in Tris-buffered saline Tween 20 buffer (TBST; $20 \mathrm{mM}$ Tris $\mathrm{HCl}, 0.9 \% \mathrm{NaCl}$ and $0.05 \%$ Tween 20 ) and washed at room temperature (RT) for $3 \times 5 \mathrm{~min}$ in TBST buffer. The membranes were subsequently incubated with ovine $\mathrm{Bm} 86$ or control antisera diluted 1:2500 in TBST buffer for $1 \mathrm{~h}$ at RT followed by 3 $\times 5$ min washing with TBST. Incubation with secondary rabbit antiserum to sheep IgG conjugated with horseradish peroxidase (Nordic Immunology, Tilburg, the Netherlands) diluted 1: 25000 for $1 \mathrm{~h}$ at RT followed by a third washing step with TBST for $3 \times 12 \mathrm{~min}$ at RT was done prior to $2 \mathrm{~min}$ incubation with ECL detection reagent (GE Healthcare) and exposure to Hyperfilm ECL (GE Healthcare).

\section{Abbreviations}

ACTB: $\beta$-actin; BTUB: $\beta$-tubulin; EGF: Epidermal Growth Factor; ELF1A: elongation factor $1 \alpha$; EST: expressed sequence tag; GAPDH: glyceraldehyde 3-phosphate dehydrogenase; GPI: glycosylphosphatidylinositol; GST: Glutathione S-transferase; H3F3A: H3 histone family 3A;

Table 4: Schedule of tick feeding employed for the synchronous feeding of all life stages from both $R$. microplus and $R$. appendiculatus on calf $147 \mid$.

\begin{tabular}{|c|c|c|}
\hline Action & Species & Time point (days) \\
\hline \multirow[t]{2}{*}{ Collection of eggs } & R. microplus & $4,10,15,20,22$ and 24 days post-oviposition \\
\hline & R. appendiculatus & 20 days post-oviposition \\
\hline Collection of unfed larvae & $\begin{array}{l}\text { R. microplus \& } \\
\text { R. appendiculatus }\end{array}$ & 21 days post-hatching ( 45 days post-oviposition) \\
\hline Placement of unfed larvae & $\begin{array}{l}\text { R. microplus \& } \\
\text { R. appendiculatus }\end{array}$ & 0 \\
\hline Collection of partially fed larvae & $\begin{array}{l}\text { R. microplus \& } \\
\text { R. appendiculatus }\end{array}$ & 4 \\
\hline Collection of pharate nymphs & $\begin{array}{l}\text { R. microplus } \\
\text { R. appendiculatus }\end{array}$ & $\begin{array}{l}6 \\
7 \text { days post-engorgement }\end{array}$ \\
\hline Collection of unfed nymphs & $\begin{array}{l}\text { R. microplus } \\
\text { R. appendiculatus }\end{array}$ & $\begin{array}{l}7 \\
21 \text { days post-molting }\end{array}$ \\
\hline Placement of unfed nymphs & R. appendiculatus & 7 \\
\hline Collection of partially fed nymphs & $\begin{array}{l}\text { R. microplus \& } \\
\text { R. appendiculatus }\end{array}$ & 11 \\
\hline Collection of pharate adults & $\begin{array}{l}\text { R. microplus } \\
\text { R. appendiculatus }\end{array}$ & $\begin{array}{l}13 \\
7 \text { days post engorgement }\end{array}$ \\
\hline Collection of unfed males & $\begin{array}{l}\text { R. microplus } \\
\text { R. appendiculatus }\end{array}$ & $\begin{array}{l}\text { I4 } \\
21 \text { days post-molting }\end{array}$ \\
\hline Collection of unfed females & $\begin{array}{l}\text { R. microplus } \\
\text { R. appendiculatus }\end{array}$ & $\begin{array}{l}15 \\
21 \text { days post-molting }\end{array}$ \\
\hline Placement of unfed adults & R. appendiculatus & 15 \\
\hline Collection of partially fed adults & $\begin{array}{l}\text { R. microplus \& } \\
\text { R. appendiculatus }\end{array}$ & 22 \\
\hline
\end{tabular}


ORF: Open Reading Frame; PBS: Phosphate Buffered Saline; PPIA: cyclophilin; p.o.: post oviposition; RPL4: ribosomal protein L4; RT: room temperature; TBP: TATA box binding protein; TBST: Tris-buffered saline Tween 20 .

\section{Authors' contributions}

AMN conceived and performed the experiment and drafted the manuscript. JB and MP assisted in the protein isolations, Western Blots and cloning and sequencing of Ra86. FJ supervised the study and helped to draft the manuscript. All authors read and approved the final version of the manuscript.

\section{Additional material}

\section{Additional file 1}

Additional figure 1. Nucleotide sequence and derived amino acid sequence of the two sequenced Ra86 alleles.

Click here for file

[http://www.biomedcentral.com/content/supplementary/14712199-10-112-S1.DOC]

\section{Acknowledgements}

The antisera used were a kind gift of Dr. Peter Willadsen from CSIRO Livestock Industries, Queensland, Australia. Peter Willadsen is also thanked for his valuable suggestions which helped to improve this paper. This research was supported by the Wellcome Trust under the 'Animal Health in the Developing World' initiative through project 075799 entitled 'Adapting recombinant anti-tick vaccines to livestock in Africa'.

\section{References}

I. Walker AR, Bouattour A, Camicas J-L, Estrada-Pena A, Horak IG, Latif AA, Pegram RG, Preston PM: Ticks of domestic animals in Africa: a guide to identification of species. Edinburgh: BioScience Reports; 2003.

2. Gough JM, Kemp DH: Localization of a low abundance membrane protein $(\mathrm{Bm} 86)$ on the gut cells of the cattle tick Boophilus microplus by immunogold labeling. J Parasitol 1993 79(6):900-907.

3. Fragoso H, Rad PH, Ortiz M, Rodriguez M, Redondo M, Herrera L, de la Fuente J: Protection against Boophilus annulatus infestations in cattle vaccinated with the $B$. microplus $B m 86$-containing vaccine Gavac. Vaccine 1998, 16(20): 1990-1992.

4. de Vos S, Zeinstra L, Taoufik O, Willadsen P, Jongejan F: Evidence for the utility of the Bm86 antigen from Boophilus microplus in vaccination against other tick species. Exp Appl Acarol 200I, 25(3):245-26I.

5. Odongo D, Kamau L, Skilton R, Mwaura S, Nitsch C, Musoke A, Taracha E, Daubenberger C, Bishop R: Vaccination of cattle with TickGARD induces cross-reactive antibodies binding to conserved linear peptides of Bm86 homologues in Boophilus decoloratus. Vaccine 2007, 25(7): I287-1296.

6. Guerrero FD, Miller RJ, Rousseau ME, Sunkara S, Quackenbush J, Lee Y, Nene V: BmiGl: a database of cDNAs expressed in Boophilus microplus, the tropical/southern cattle tick. Insec Biochem Mol Biol 2005, 35(6):585-595.

7. Nene V, Lee D, Kang'a S, Skilton R, Shah T, de Villiers E, Mwaura S, Taylor D, Quackenbush J, Bishop R: Genes transcribed in the salivary glands of female Rhipicephalus appendiculatus ticks infected with Theileria parva. Insect Biochem Mol Biol 2004 34(10): $1117-1128$.
8. Wang M, Guerrero FD, Pertea G, Nene VM: Global comparative analysis of ESTs from the southern cattle tick, Rhipicephalus (Boophilus) microplus. BMC Genomics 2007, 8:368.

9. Bustin SA: Absolute quantification of mRNA using real-time reverse transcription polymerase chain reaction assays. J Mol Endocrinol 2000, 25(2): 169-193.

10. Vandesompele J, De Preter K, Pattyn F, Poppe B, Van Roy N, De Paepe A, Speleman F: Accurate normalization of real-time quantitative RT-PCR data by geometric averaging of multiple internal control genes. Genome Biol 2002, 3(7):RESEARCH0034.

II. Andersen CL, Jensen JL, Orntoft TF: Normalization of real-time quantitative reverse transcription-PCR data: a model-based variance estimation approach to identify genes suited for normalization, applied to bladder and colon cancer data sets. Cancer Res 2004, 64( I 5):5245-5250.

12. Rand KN, Moore T, Sriskantha A, Spring K, Tellam R, Willadsen P, Cobon GS: Cloning and expression of a protective antigen from the cattle tick Boophilus microplus. Proc Natl Acad Sci USA 1989, 86(24):9657-966|.

13. de Jonge HJ, Fehrmann RS, de Bont ES, Hofstra RM, Gerbens F, Kamps WA, de Vries EG, Zee AG van der, te Meerman G], ter Elst A: Evidence based selection of housekeeping genes. PLOS ONE 2007, 2(9):e898.

14. Freitas DR, Rosa RM, Moraes J, Campos E, Logullo C, Da Silva Vaz I Jr, Masuda A: Relationship between glutathione S-transferase, catalase, oxygen consumption, lipid peroxidation and oxidative stress in eggs and larvae of Boophilus microplus (Acarina: Ixodidae). Comp Biochem Physiol A Mol Integr Physiol 2007, I 46(4):688-694.

15. Saldivar L, Guerrero FD, Miller RJ, Bendele KG, Gondro C, Brayton $\mathrm{KA}$ : Microarray analysis of acaricide-inducible gene expression in the southern cattle tick, Rhipicephalus (Boophilus) microplus. Insect Mol Biol 2008, I7(6):597-606.

16. de la Fuente J, Blouin EF, Manzano-Roman R, Naranjo V, Almazan C Perez de la Lastra JM, Zivkovic Z, Jongejan F, Kocan KM: Functional genomic studies of tick cells in response to infection with the cattle pathogen, Anaplasma marginale. Genomics 2007, 90(6):7|2-722.

17. Canales M, de la Lastra JM, Naranjo V, Nijhof AM, Hope M, Jongejan F, de la Fuente J: Expression of recombinant Rhipicephalus (Boophilus) microplus, $R$. annulatus and $R$. decoloratus Bm86 orthologs as secreted proteins in Pichia pastoris. BMC Biotechnol 2008, 8: 14.

18. Sossai S, Peconick AP, Sales-Junior PA, Marcelino FC, Vargas MI, Neves ES, Patarroyo JH: Polymorphism of the bm86 gene in South American strains of the cattle tick Boophilus microplus. Exp Appl Acarol 2005, 37(3-4):199-2।4.

19. Murrell A, Barker SC: Synonymy of Boophilus Curtice, 1891 with Rhipicephalus Koch, 1844 (Acari: Ixodidae). Syst Parasito 2003, 56(3): 169-172.

20. Jasik K, Buczek A: Origin of alimentary tract in embryogenesis of Ixodes ricinus (Acari: Ixodidae). J Med Entomol 2005, 42(4):54I-547.

21. Kammah KME, Adham FK, Tadross NR, Osman M: Embryonic development of the camel tick Hyalomma dromedarii (Ixodoidea: Ixodidae). Int J Acarol I 982, 8(I):47-54.

22. Kemp DH, Pearson RD, Gough JM, Willadsen P: Vaccination against Boophilus microplus: localization of antigens on tick gut cells and their interaction with the host immune system. Exp Appl Acarol 1989, 7(I):43-58.

23. De Rose R, McKenna RV, Cobon G, Tennent I, Zakrzewski H, Gale $\mathrm{K}$, Wood PR, Scheerlinck JP, Willadsen P: Bm86 antigen induces a protective immune response against Boophilus microplus following DNA and protein vaccination in sheep. Vet Immunol Immunopathol 1999, 71(3-4): 15I-160.

24. Balashov YS: Bloodsucking ticks (Ixodoidea)-vectors of disease in man and animals. Volume 8. Miscellaneous Publications of the Entomological Society of America; 1972:5376.

25. Coons LB, Rosell-Davis R, Tarnowski BI: Bloodmeal digestion in ticks. In Morphology, Physiology, and Behavioral Biology of Ticks Edited by: Sauer JR, Hair JA. New York: John Wiley \& Sons; 1986:248-279.

26. Agbede RI, Kemp DH: Digestion in the cattle-tick Boophilus microplus: light microscope study of the gut cells in nymphs and females. Int J Parasitol | 985, I 5(2):|47-| 57. 
27. Agyei AD, Runham NW: Studies on the morphological changes in the midguts of two ixodid tick species Boophilus microplus and Rhipicephalus appendiculatus during digestion of the blood meal. Int J Parasitol 1995, 25(I):55-62.

28. Walker AR, Fletcher JD: Histology of digestion in nymphs of Rhipicephalus appendiculatus fed on rabbits and cattle naive and resistant to the ticks. Int J Parasitol I987, I7(8):|393-I4II.

29. Sonenshine DE: Biology of ticks. Volume I. New York: Oxford University Press; 1991.

30. Tellam RL, Smith $D$, Kemp DH, Willadsen P: Vaccination against ticks. In Animal Parasite Control Utilizing Biotechnology Edited by: Yong WK. Boca Raton: CRC Press; 1992:303-331.

31. Eisenhaber B, Bork P, Eisenhaber F: Prediction of potential GPImodification sites in proprotein sequences. J Mol Biol 1999, 292(3):74|-758.

32. geNorm manual, update July 8, 2008 [http://medgen.ugent.be/ jivdesomp/genorm/geNorm manual.pdf]

33. Patarroyo JH, Portela RW, De Castro RO, Pimentel JC, Guzman F, Patarroyo ME, Vargas MI, Prates AA, Mendes MA: Immunization of cattle with synthetic peptides derived from the Boophilus microplus gut protein (Bm86). Vet Immunol Immunopathol 2002, 88(3-4): $163-172$.

Publish with Bio Med Central and every scientist can read your work free of charge

"BioMed Central will be the most significant development for disseminating the results of biomedical research in our lifetime. "

Sir Paul Nurse, Cancer Research UK

Your research papers will be:

- available free of charge to the entire biomedical community

- peer reviewed and published immediately upon acceptance

- cited in PubMed and archived on PubMed Central

- yours - you keep the copyright

Submit your manuscript here:

http://www.biomedcentral.com/info/publishing_adv.asp
BioMedcentral 